\title{
Harold James
}

\section{Continuities and Structural Breaks in German Economic History in the Twentieth Century}

In order to be able to decide what constitutes structural breaks, it is important to identify what are the basic or underlying long term trends of German (and indeed European) history in the twentieth century. A fundamental pattern of European economic development could be described alternately in terms of:

- globalization (integration in the world economy with substantial flows of goods, but also of capital and labor), the reactions against it and the creation of a national economy, and then re-globalization in the second half of the century. This pattern can be depicted in a graphic form as a $U$, with a high degree of integration at the beginning and end of the century, and low integration in the turbulent middle.

- increased incomes as a result of technological change and sustained rises in productivity. If we try to present this result graphically, we see a major series of disruptions and breaks in the middle years of the century. But we may find it possible to calculate a trend from beginning to end that would also supply a hypothetical or counter-factual version of what might have occurred in the mid-century, if political circumstances had been different. Such an exercise underlies Borchardt's analysis of the sickness (or below capacity performance) of the Weimar economy'.

These two trends are related to each other, most obviously because of the importance of the transnational transfer of technologies. The period of deglobalization was also the least satisfactory in terms of growth or welfare. Neither of the two basic trends, globalization and prosperity, were driven by political decisions or processes.

Political expectations reflect some of these economic experiences but not of course all of them. In terms of the political chronology, and of social psychology, there can be little doubt that the big political caesuras of 1914, 1933, 1945, and 1989 had a profound impact. They also shaped the institutions, which dealt with the consequences of economic growth, or its absence. But there are also some caesuras set by the world economic context, which raised new questions about the responsiveness of political institutions. Such a caesura occurred in the 1970s, with

1 Knut Borchardt, Perspectives on Modern German Economic History and Policy (translated by Peter Lambert) (Cambridge 1991). 
the two oil crises, the phenomenon of stagflation, the questioning of growth, and the display of the limits of Keynesianism.

\section{Deglobalization}

The particular steps or turning points in the story of deglobalization can be defined in outline as:

1914: the outbreak of war destroyed the integrated international economy that had emerged in the late nineteenth century. But even before 1914, there had been an extensive polemic, in which many - especially on the agrarian right - attacked the international linkages of the gold standard. Conservative German politicians began to see their currency in mercantilist terms, and to complain of the loss of gold. One deputy told the Reichstag of the old song: "What's the use of a pretty girl, when others take her for a whirl?" 2 The demand for trade protection had of course been a central issue of German political life since the 1870s. After 1914, the arguments of those who had argued against international linkages on security grounds became louder and also more plausible: international trade reduced the capacity to supply food, and international financial flows made the monetary system vulnerable to politically induced speculative attacks, such as that mounted by France against German financial institutions during the 1911 Morocco crisis.

1923-1924: the return to the international economy occurred with a commitment to a restoration of a modified version of the international gold standard (gold exchange standard). But the new international monetary order contained a substantial potential for destabilization. The gold standard was a mechanism for restoring credibility in currency stabilization, but it also was a perfect mechanism for transferring monetary shocks across national frontiers. The deflationary potential of the gold exchange standard was increased by the adoption of fractional reserve requirements (in the German case, the requirement of a 40 percent cover of note issue by gold or foreign exchange).

1931: a contagious currency crisis, of which central Europe (Austria, Hungary and Germany) was an epicenter, destroyed the international monetary order. As Ritschl recently pointed out, the parallel character of two claims on German foreign exchange earnings - reparations and the service of commercial debt-contributed to a debt-overhang that provided the basis of a panic by creditors, and thus a withdrawal of funds ${ }^{3}$. Germany adopted exchange controls that were progressively tightened in the course of the 1930 s, and were used as a model by other coun-

2 Raab in Reichstag on January 15, 1908, Reichstag, Vol. 229, p. 2445. „Was nürzet mir ein schönes Mädchen, wenn andere damit spazieren gehen?"

3 Albert Ritschl, Deutschlands Krise und Konjunktur 1924-1934: Binnenkonjunktur, Auslandsverschuldung und Reparationsproblem zwischen Dawes-Plan und Transfersperre (Berlin 2002). 
tries, above all in central Europe (so that "Schachtianism" became a form of economic management).

1933: the political revolution that followed from the Nazi seizure of power made the choice of national economic policies over the international order fully apparent. The Nazi economic ideology blamed "internationalism" as connected with the reparations system, and with damaging (and Jewish) speculation.

1948-1949: the creation in eastern Germany of a socialist state preserved some of the elements of the command economy, cut off from international developments, as it had evolved during the Nazi era. Some analysts have interpreted the GDR experience as a guide to what Nazi economics might have resulted in, in the counter-factual case of an absence of war ${ }^{4}$. Artificial prices repressed the market mechanism, and led to deteriorations in efficiency and in the quality of goods produced. Thus though there were very high levels of investment in the GDR, and these were often assumed by naive observers to be the major determinant of economic growth, the results were surprisingly disappointing.

\section{Reglobalization}

Like the destruction of the global framework, the course of reglobalization also was not a simple process that resulted from one unique set of policy choices, though there were some landmark events that set the points for the future journey of Germany into the world economy: above all, the implementation of a currency reform and price liberalization in 1948; the decision in 1950 not to reimpose controls in the light of a large external deficit; and the acceptance of the Treat of Rome (1957).

The course of integration required, however, above all a new sort of international order, in which economic liberalism became "embedded" (to use the phrase of Ruggie) in regular economic transactions ${ }^{5}$. There was a new monetary framework, as elaborated by the United Nations Monetary and Economic Conference at Bretton Woods (July 1944), in which the authors of a new monetary order, notably John Maynard Keynes and Harry Dexter White, set out a vision that was different to both the gold standard and its interwar variant, and to Schachtianism. It was designed, for instance, to eliminate multiple exchange rates, which had been an important element of the management of trade in the 1930s. Most importantly, the agreement provided for a move to the restoration of convertibility of current account transactions (but not capital account transactions, which the makers of Bretton Woods still felt should be controlled).

${ }^{4}$ Christoph Buchbeim, Die Wirtschaftsentwicklung im Dritten Reich - mehr Desaster als Wunder, in: Vierteljahrshefte für Zeitgeschichte 49 (2001) 653-664.

5 John Gerard Ruggie, Winning the Peace: America and World Order in the New Era (New York 1996). 
An important source of growth in the 1950s was trade liberalization in the framework of the GATT, the gradual move to current account convertibility, and the consequent dramatic expansion of trade (later, after 1958, redirected in the framework of the EEC). The European Recovery Program had allowed investment directed at the overcoming of specific bottlenecks that would otherwise have been a hindrance to growth (such as coal mining, machine tools, and the provision of electrical power). The institutional features of the postwar order can be described as the reintegration of Germany in the world economy (see Buchheim) ${ }^{6}$.

But that postwar order can also be viewed as the creation of circumstances, which allowed the evolution of a distinctively German version of economic growth, built around a number of major elements that replaced previous sources of instability in German political economy.

1. The stable currency. This was the legacy of the 1948 currency reform, and was widely seen as a, if not the, major success of postwar Germany. At the time of this reform, largely imposed by the Allies, Germany had had a reputation as an inflationist culture. Two great inflations, associated with military spending and war, had over thirty years twice destroyed the value of the German currency. The first inflation was widely credited with destroying the political stability of Weimar Germany. Some writers, notably Elias Canetti, even made a causal link between the hyperinflation and the holocaust, arguing that Germans had been conditioned to see humans in large quantities as statistically insignificant, and analogous to the zeroes that proliferated at the time of the inflation.

The link between inflation and the over-extension of political expectations was actually vividly described in advance by the banker and economist Karl Helfferich. Helfferich started off with a criticism of the gold standard. It would, he suggested, be possible in theory to generate a constant price standard of value more easily with a paper currency. In that sense the development of the early twentieth century corresponded to a deep historical logic. Helfferich concluded, "that in a certain sense paper currency represents the logical culmination of the history of money"7. But Helfferich immediately saw the disadvantages: if the state defined the value of money, there would be a politicization of money, as debtors and creditors would organize politically and press for the monetary policy appropriate to their circumstances: inflation and deflation respectively. To some extent this had occurred already in the debates of the 1890 s about the deflation, when farmers demanded the introduction of an inflationary bi-metallic (silver and gold) standard. "As much as at first sight an advantage of a pure paper currency lies in the ability of the state to keep the value of the currency absolutely stable by regulating the issue of money according to the demand, in practice there are considerable difficulties ... On the one hand, all who owe money would plea for as large an issue of

6 Christoph Buchbeim, Die Wiedereingliederung Westdeutschlands in die Weltwirtschaft 1945-1958 (München 1990).

7 Karl Helfferich, Das Geld (Leipzig 21910) 588: „dass in gewissem Sinne das reine Papiergeld den äußersten Punkt der Entwicklungsgeschichte des Geldes bildet“". 
money as possible in order to diminish the value of money; on the other hand, creditors and recipients of fixed incomes, wages, salaries and pensions, would fight for an increase in the value of money. The struggle over the value of money would lead more than any other conflict of interests to a demoralization of economic and social life." It is hard to think of a more stunningly accurate prediction of the experiences of Germany with paper money in the three decades after 1914. What gives the prophecy a particularly delicate irony is that Helfferich was the man who, as Interior and then Treasury Secretary during the First World War, did most to set off that process that he had so accurately described. The process of inflation, with its polarization of groups into interest-based coalitions fighting redistributive battles through the control and manipulation of the money supply, was an ultimately logical outcome of the decisions of the early 1870 s, to subject money to national decision-making, or to create a national money. In the end, the idea and the practice of national money practically destroyed the nation as a community of fate (Schicksalsgemeinschaft).

The new monetary stability after the 1948 currency reform symbolized a more general self-limitation in German politics that would be a fundamental building block for a new political society, in which limits were to be set on political choices in order to prevent a self-destructive building up of mutually contradictory claims. The Deutsche Mark was stable because its institutional setting limited politically seductive opportunities for fiscal and monetary expansionism.

At the beginning, however, this stability had been endowed externally, and there was a great deal of fear and worry about the effects of the currency reform. It is remarkable how quickly the German economic miracle made for an internalization of the values of stability. Already by the later 1950 s, Germans believed that threats to stability no longer came from internal political problems, but from the outside, from the dollar glut following U.S. military expenditure and overseas investments by U.S. corporations. Now it was the rest of the world that was inflationary, and the DM that had become the source of stability and confidence.

In this regard, the role of the Deutsche Mark was quite the opposite of the international history of the U.S. dollar. For the United States, the dollar frequently appeared as more than simply a national symbol. It was a weapon in international politics, as the United States was able to threaten dollar depreciation as a way of enforcing its trade policy. Especially since the Presidency of Richard Nixon, the dollar stood for what could be obtained by politics, rather than for the limitations

8 Ibid. 589-590. „So sehr man auf den ersten Blick einen Vorteil der reinen Papierwährung darin erblicken mag, dass sie die Staatsgewalt in die Lage setze, durch eine Regulierung der Geldausgabe nach dem Geldbedarfe den Geldwert in voller Stabilität zu erhalten, so große Schwierigkeiten würden der praktischen Verwirklichung dieses Vorteils entgegenstehen. ... Auf der einen Seite würden alle, die Geld schulden, für eine möglichst starke Geldausgabe und die möglichste Verringerung des Geldwertes kämpfen, auf der anderen Seite würden alle Gläubiger und alle diejenigen, die feste Gehälter, Renten und Löhne empfangen, an einer Hochhaltung und Steigerung des Geldwertes interessiert sein. Der Kampf um den Geldwert müsste mehr als jeder andere wirtschaftliche Interessenkonflikt zur Demoralisation des wirtschaftlichen und gesellschaftlichen Lebens führen." 
on political action. To use a popular American phrase, the dollar is a "can do" currency (while the Deutsche Mark was a "cannot do" currency).

After the crises of the early 1970s and the collapse of the Bretton Woods system, which it blamed on the mismanagement of the U.S. dollar, the German Bundesbank drew the corresponding lesson. It searched for a rule-based approach to monetary management, in the form of monetary targets, which it saw as the guarantor of "stability culture".

2. Social Partnership (the extension of the principle of Mitbestimmung). Interwar German democracy had been plagued by bitter distributional conflicts, between labor and capital, as well as within the labor movement and employer organizations. The postwar order set out to bind labor into a new compromise. At the company level, this was to be done by laws on employee representation. A fifty percent codetermination was established by the law of 1951 for coal or steel companies (Montanindustrie), in other words in the basic industrial sectors where the conflicts of interwar Germany had been most acute. In 1956 the provisions of the 1951 law were extended to the parent companies of Montan business, and the fifty percent regulation was eventually extended to all larger companies, but only in 1976.

3. Social Inclusiveness. The extension of welfare state provisions was closely linked to the creation of political legitimacy. A dramatic instance was the 1957 pensions reform, which was a prelude to the only election in the Federal Republic when one party gained more than half the total vote.

The concept of soziale Marktwirtschaft was an elusive one, and in the hands of Ludwig Erhard and of the leading members of the ordo-liberal school, there was some rhetorical fudging that presented the new order as a third or middle way between the dangerous extremes of socialism and the planned economy on the one hand, and nineteenth century "Manchesterism" or "paleo-liberalism". Sometimes Erhard even described himself as a planner, providing that the plan encompassed organic rather than artificial growth?.

4. Macro-economic stabilization policies. There was less discussion of this in the 1950 s than in the 1960 s, particularly when a small economic downturn in 1966-1967 was linked with an upsurge of political extremism on the right as well as the left. A lively debate started about whether Bonn was Weimar. The response of the Great Coalition after 1966 was to emphasize macro-economic and fiscal means of combating unemployment and recession. In particular the $1967 \mathrm{Law}$ on Stability and Growth strikingly took up the arsenal of Keynesian demand management as a way of reconciling the elements of a "magic quadrangle" of price stability, growth, full employment, and balanced external accounts. The major architect, Karl Schiller, spoke of a Globalsteuerung that would facilitate but not distort individual choices: a view not very far from Erhard's view about what sorts of planning might be appropriate. By this time, there was a substantial degree of con-

9 A. J. Nicholls, Freedom with Responsibility: the Social Market Economy in Germany, 1918-1963 (Oxford 1994). 
sensus about appropriate economic policy management between the two major parties. The SPD had initially been highly critical of Erhard, but by 1959 in the Bad Godesberg Program provided a classic description of the ideal of soziale Marktwirtschaft.

These four elements provided a basis for the evolution of a consensus between the major parties, around soziale Marktwirtschaft, that was quite different from the original postwar concepts of macro-economic management, and which were later identified by Helmut Schmidt (above all in the 1976 Bundestag election) as the Modell Deutschland. It was widely admired, and many observers in Britain and the United States saw this model (or an analogous Japanese one that also emphasized social solidarity at the expense of individualism) as generating faster and better (i.e. more just) long term economic growth.

\section{The Limits of the National Economy}

Just as the idea of a Modell Deutschland was being worked out intellectually and politically, it was challenged by a new wave of globalization, in particular the increase in international capital mobility. By the late 1960 s inflation posed a major challenge to the stability of the "magic quadrangle". Many Germans saw the source as external, emanating from the international monetary system and the U.S. mishandling of the dollar - especially during the Nixon presidency after 1969. In the debates about international economic policy in the early 1970s (and in conflict with Karl Schiller, who held a classically liberal position on the external account issue), Finance Minister Helmut Schmidt identified capital mobility as the source of a fundamental threat. For the moment, Schmidt rather than Schiller won.

The new wave of globalization driven by capital mobility threatened the German model and German prosperity. After the 1970s, there was a new internationalization of finance, of enterprises, and a continually increasing threat to the classic model of German industrial relations. In particular the steel crisis of the later 1970 s showed the extent of the vulnerability of a sector that had since the mid-nineteenth century been at the heart of the German economy and of economic policy-making. The model of Mitbestimmung, in which the legal provisions applied to German companies and required the representation on the supervisory board of their German workforce, looked odd when companies were internationalized, and foreign workers were not included in the representation.

The challenge of internationalization can be seen at a level of enterprise history, as well as in the new challenges facing economic policy. The German enterprise as reconstituted in the Erhard Wirtschaftswunder years was quite recognizably the traditional German enterprise. One influential analysis of the roots of the postwar economic resurgence (by Olson) has emphasized the way in which in Germany and Japan military defeat broke up old special interest clusters that acted to impede growth, and allowed the formation of associations more geared to an overall 
good $^{10}$. But it is striking how superficial much of the breaking-up was, and how quickly the new order allowed the reemergence of traditional ways of doing business. In Japan, Italy and Germany defeat and occupation actually encouraged a reemergence of a kind of business structure, family capitalism, that offered an alternative to state-centered approaches. In a period of political upheaval, it is natural to think that the family and its internalized bonds of trust allowed for a return of confidence.

Attempts by the Allies at deconcentration and decartellization only produced after a decade a restoration of some of the old structures in banking and industry. The major commercial banks were broken up into regional banks, at first on a Land basis, but they then recombined to form units for the western occupation zones, and by 1957 they reconstituted themselves as single entities for the Federal Republic. The steel industry was broken up, and iron and steel separated from coalmines. But in the 1960s, a big merger movement began and companies such as the August Thyssen Hütte recaptured some of their former dominance in a different form. Codetermination (like the Allied deconcentration initiative, with which it had originally been linked) was an external intervention that by acting as an irritant in German corporate life in the event actually acted as a stimulant to traditional industry to reformulate and reassert its interests. In the first instance, it encouraged steel businesses to look elsewhere and try to escape from being part of Montanindustrie. The legislator then tried to catch up with them, with a gradual extension of the principle of co-determination. But then the flight continued; and in 1967 and 1971 new legislative initiatives delayed companies' exit from Mitbestimmung in cases where the basis of production had changed ${ }^{11}$.

Family ownership, even for major industrial holdings, could be reconstituted. At first this long-standing structural feature of German business life had appeared threatened by the military and political collapse of Germany. It was not just the obvious armaments suppliers, the Krupps and Flicks, who were the focus of Allied attention. For instance, the OMGUS investigation of the GHH began with the observation that: "The Ruhr with its big family combines is a classical place to study the influences of family complexes on the economic and political destinies of a country." Descendants of the two Haniel brothers, Franz and Gerhard, in 1906 had owned 77 percent of the share capital of the GHH. On September 1, 1939, they still owned 65 percent, and this ratio was more or less unchanged through the War, when there had been few share transactions: On May 8, 1945, the day of the German surrender, it was still 64 percent. But on August 15, 1951, the Haniels only owned 35 percent of the capital of GHH. The New York law firm, which represented the GHH in its dealings with the Allied High Commission,

10 Mancur Olson, The Rise and Decline of Nations: Economic Growth, Stagflation, and Social Rigidities (New Haven 1982).

11 See Gloria Müller, Montanmitbestimmung bei Eisen und Stahl. Eine Momentaufahme in der Geschichte, in Ottfried Dascher, Christian Kleinschmidt (eds.), Die Eisen- und Stahlindustrie im Dortmunder Raum: wirtschaftliche Entwicklung, soziale Strukturen und technologischer Wandel im 19. und 20. Jahrhundert (Dortmund 1992) 511-524. 
Shearman and Sterling and Wright, reported that "the drop from 1945 to 1951 has been due primarily to expenses for estate and property taxes and the necessity of living out of capital. Most of the substantial owners are advanced in years and the prospects are that estate taxes will continue to reduce the holdings."

In fact, however, the Haniel family interest regrouped using a trading company, Franz Haniel und $\mathrm{Cie}$ as a vehicle, and family capitalism was quickly reestablished. The family model of enterprise was also a characteristic of the many new Mittelstand firms, which provided a powerful basis for the economic recovery.

Germany remained a land of family capitalism, despite some erosion after the 1970 s. At the beginning of the twenty-first century 25.0 percent of the total market value of listed corporate assets in Germany was controlled by just fifteen families (and 15.7 percent by five families). For Italy, which is usually considered the classical land of family capitalism, the equivalent figures are 21.9 percent and 16.8 percent. By contrast, in the United Kingdom, the equivalent figures are just 6.6 percent and 4.1 percent ${ }^{12}$.

The story of a German restoration can also be told at the enterprise level in terms of personal and managerial continuities. For instance, there is the famous case of Hermann Josef Abs at Deutsche Bank, who was both the star of the bank after 1938, and the major force behind the reconstruction of the enterprise in the 1950 s. Born in 1901, he was a representative of the "Jahrhundertgeneration" that has been the focus of much discussion by those who see German history in terms of the conflict of generational cohorts ${ }^{13}$. The vision of the bank that he propounded was entirely traditional. But it depended upon a large measure of regulation and control, with interest rates fixed until the 1970s, so that bankers could say that they would know at the start of each year what they earn by the end of the year ${ }^{14}$. The new uncertainties required the formulation of a flexible planning process that was possible only on the basis of advanced electronic data processing capacity. The bank became what Hans Büschgen called "an open sociotechnical system" rather than a carefully delineated hierarchical pyramid of decision making. By the mid-1980s, the old (now retired) bankers like Abs were quite open in their contempt for the new generation of managers, in particular Alfred Herrhausen, who had in effect created a new institution ${ }^{15}$.

Any traditional model of the firm was threatened by a new industrial and managerial revolution in the 1970s; and then by the inability of Mittelstand families to reproduce themselves as business units, as the ideas underlying family existence were subject to a profound transformation.

12 Mara Faccio, Larry H. P. Lang, The Ultimate Ownership of Western European Corporations, in: Journal of Financial Economics 65 (2002) 393.

13 See Thomas Kobut, Jürgen Reulecke, Die Jahrhundertgeneration: Geschichte und Geschichten von Deutschland im Jahrhundert (forthcoming).

14 Hans Büschgen, Deutsche Bank: 1957 to the Present, in: Lothar Gall et al., The Deutsche Bank, 1870-1995 (London 1995) 550.

15 There is a popular but revealing account of this tension in Andres Veiel, Black Box BRD (München 2002). 
Traditionally, Germany had been a country of producer or investment goods, and the arrangements for soziale Marktwirtschaft represented an agreement between producers: labor and capital. But the 1960 s was the era of especially rapid growth in consumer goods industries in which it was important to respond to rapidly changing individual choices. The most characteristic or at least the most flamboyant entrepreneurs, who celebrated a new style of business, were no longer working in heavy industry. They were concerned above all with the development of consumer markets: in developing innovative approaches to retailing (Otto Versand, Neckermann, Quelle, Otto Beisheim's Metro), in publishing (Reinhard Mohn's Bertelsmann, or Franz and Aenne Burda's publications), and consumer electronics (Max Grundig). They popularized a mission of creating a new egalitarianism of consumption. Neckermann called it "using high class goods to make class obsolete", and added that "the market is the world of dreams becoming reality"16.

The socialist critic Hans Magnus Enzensberger subjected the Neckermann catalogue to an amusingly accurate, but also rather snobbishly condescending, review in 1960, which used the supply of goods as a barometer test of national taste and opinion in Germany: "The autumn catalogue is more precise and more incorruptible than any demoscopic investigation. It doesn't register non-committal answers to non-committal questions, but rather the decisions of a compact majority, which pays in cash ... An article must be created in such a way, that it can unite a majority behind it. The catalogue is more than a result of a normal commercial calculation: it is the result of an invisible plebiscite."17 The cultivation of consumer markets required an ability quickly to respond to shifts in demand and fashion: and this could not be carefully planned in the way that had been a part of the traditional German industrial culture.

The new environment required flexibility and an approach, which saw output not in terms of particular products but of inter-connected systems that needed continual updating. The model for much of the new approach was provided by IBM. IBM did not sell a product: the mainframe computers of the 1960 s and 1970 s were leased rather than sold, and IBM regarded its major activity as the provision of continual service of a complex combination of hardware and software. Former IBM Deutschland managers went into many other parts of German business life (one, Hans Olaf Henkel, became President of the Employers' Federation). And they brought their approach with them.

16 „Wir überwinden die Klassen durch Güter von Klasse ... Der Markt ist zur Wirklichkeit werdende Traumwelt", from Josef Neckermann, Erinnerungen (Frankfurt a.M. 1990) 279.

17 „Es [dieses Werk] ist unbestechlicher und genauer als jede demoskopische Untersuchung. Nicht unverbindliche Antworten auf unverbindliche Umfragen werden hier registriert, sondern Beschlüsse der kompakten Majorität, die in bar bezahlt werden ... Er [der Artikel] muß so beschaffen sein, daß sich eine Mehrheit auf ihn einigen kann. Der Katalog ist somit mehr als das Resultat einer normalen kaufmännischen Kalkulation: er ist das Resultat eines unsichtbaren Plebiszits." Hans Magnus Enzensberger, Das Plebiszit der Verbraucher, reprinted in Einzelheiten (Frankfurt 1962) 137-138. 
Information technology and internationalization (which interact with each other) transformed the traditional enterprise. Thus, although there has been a great deal of emphasis in some accounts on the novelty of the Federal Republic and the "Americanization of West German industry" (as Berghahn expressed it in the title of a rightly celebrated book), the basic structural break actually occurred rather later and involved a deep caesura with traditional German ways of doing business.

\section{Conclusion}

This approach to the chronology of economic change and challenges offers an alternative to a dating that tells the story of economic shifts mostly in terms of major political structural breaks. The greatest economic break in this version appears in the 1970s, when there were no great or obvious political turning points (the whole of the 1970s was managed by a left-center coalition government). In this version, in the period of deglobalization (1910s to 1970s), Germany operated first a largely unsuccessful national economy (1919-1945), and then (in western Germany) a largely successful version (1948-1973). But both were systems in which political decisions about economic policy laid down the basis for the outcome of distributional struggles, and politicians claimed that they deserved credit for economic success. Hjalmar Schacht in the 1930s liked to refer to a Wirtschaftswunder, and Erhard in the 1950s was happy to be seen as the father of economic recovery (though he disliked the term Wirtschaftswunder, in part because of its Schachtian connotations). The previous and subsequent periods were rather different. In these eras, the absence of policy choices led to a disappointment of expectations about what politics could do, and to a general disenchantment (the phenomenon of modern Germany known as Politikverdrossenbeit). The widely shared model of the political direction of economic processes was under attack. 
